four spectroscopes fed by the light reflected by a siderostat of 30 cent. diameter, these four spectroscopes being bracketed together very much like a Gatling gun, and pointed to the siderostat, which has a very excellent clock attached to it. The first spectroscope, called the "Hilger," in the programme, is an integrating one, and will integrate for us the light of the whole region round the sun during the entire period of totality on a plate which is allowed to fall very slowly by means of a clockwork arrangement. If any change, therefore, takes place in the spectrum of these regions during this period, it will be recorded on this moving plate in historical sequence, so that, the beginning and end of exposure being known, the time at which any definite change takes place can be determined. The Rowland grating coming next on the list, which was generously given to $\mathrm{Mr}$. Norman Lockyer by Professor Rowland, is one of ten feet focus, and has a large surface with $r 4,000$ lines to the inch, forming of course a most excellent and simple prismatic camera, the first and second order spectra both being utili ed. The prismatic camera and slit spectroscope of two prisms were two instru nents arranged by Capt. Abney for the eclipse last year. They are on the model of the instruments designed for the eclipse of 1875 in Siam, but have the advantage of possessing plates which are sensitive to the whole of the speatrum. The work to be doze by the equatorial is of a very similar nature to that to be atte npted with the siderostat, except that it was intended by varying the time of exposure from long to very short periods to make certain of something. All the cameras, except the "Hilger," in which the plate moves by clockwork, are fitted with long plates, of which only small strips are exposed at a time, an l the exposure is managed, not by changing the plate as in the ordinary method, but by turning a screw. The wor 1 "expose" in the table therefore shows the precise moment, at which, if the instructions are carried out, a new strip of plat will be exposed to the action of the light before, during, and after totality, and it will be seen that the exposures are varied both before and after totality, so as to get the greatest possible difference in time during which each part of the plate receives its impression. From a letter received by Mr. Norman Lockyer from Messrs. Lawrance and Woods, we know that the American astronomers intended giving them all possible facilities for carrying out the combined Royal Society and Solar Physics Com nittee's programme; and that the attention of the English observers will be concentrated on the siderostat and equatorials, as two offizers of the American ship have been told off to work the photo-heliographs and look after the eclipse clock, which is so arranget that it keeps all the observers together by indicating to each one of t'iem the exact number of seconds still left for his work, with the additional advantage that each number of seconds announced by the officer in charge is a distinct order to do a certain thing, as in the case of the various exposures indicated in the list.

\section{LECTURES TO WORKING MEN}

$\mathrm{T}$ $\mathrm{HE}$ three courses of Lectures to Working Men given at the Museum of Practical Geology, Jermyn Street, during the present session, by the staff of the Normal School of Sience and the Royal School of Mines, came to an end last Monday, and, as on former occasions, it gave rise to regret that more cannot be done in this direction, both with regard to the number of courses given, an 1 the number of persons accommodate 1 in each case. The theatre at Jermyn Street restricts t'ie au lience to something over 600 , while of late years the applications for tickets have never been less than 2,000. The tickets for each course-for which sixpence is charged as a registration fee-are given anly to bon $\hat{a}$ fide working.men, who must bring with

them a paper on which is stated their name and occupation. Some of the lectures' of the last course-that given by Mr. Norman Lockyer, on "The Earth and its Movements"-were listened to by the Japanese Minister, and an official connected with the Education Department of Japan. At their request a list was drawn up showing the trades of the audience. This list, in the case of 500 who attended the last course, we are permitted to give, and we think our readers will find it an interesting one. Seeing that there is this anxiety on the part of working men to learn, and that less than one in three of those so desirous of learning can have an opportunity of doing so, we trust that in future years the Lecture Theatre at South Kensington will be utilised in this direction, as well as that at Jermyn Street. There is little doubt, of course, that a Liberal Government, represented by the Treasury officials, naturally anxious in all ways to protect the public purse against all claims, whether good or bad, might object to this being done at the public cost, but seeing that the lectures are given as a labour of love by the various professors such an objection would scarcely be urged, and we confess too that we should not only like to see the theatre at South Kensington utilised in this way, but the theatres at University College, King's College, and other institutions that might be named. We do not believe that the professors at these institutions are less anxious for the progress of knowledge among the wor'zing classes than those who are connected with the Grvernment School, and this being so, we may hope to see at some future time a united effort to supply what is at present a great want, and a gap in our educational programme.

Trades of 500 of the audience at the last course of Lectures to Working Men, April and May, I883 :-

I Bag Maker.

6 Bakers.

2 Basket Makers.

28 Boot and Shoe Makers.

I Brewer.

2 Brush Makers.

I Billiard Table Maker,

6 Builders (Foremen).

I Butler.

3 Brass Fini hers.

2 Bricklayer:

7 Bookbinders.

6 Cabinet Makers.

52 Carpenters and Joi ters.

8 Coach Painters.

9 Co up ssit ors.

8 Carvers.

I Cigar Maker.

4 Chemists and Druggists.

I3 Clerks.

3 Curriers.

6 Dentists.

4 Designers.

I Die Sinker.

I Draper.

2 Draughtsmen.

25 Engineers.

2 Engravers.

I Envelıpe Maker.

I Fishing $R$ d Maker.

5 Gasfitters.

I Gardener.

7 Gilders.

$x$ Greengrocer.

2 Grainers.

3 Gla sscutters.

4 Gun Makers.

7 Hatters.

I Hairdresser.

I Hinge Maker.

x Hammerma'.

I Hemp Dresser.

23 House Painters.
6 Iron Founders.

23 Instrument Makers.

37 Jewellers.

I Lamp Maker.

I Lead Glazier.

3 Lithographers.

I Locksmith.

4 Stonemasons.

I Mattress Maker.

2 Milkmen.

6 Opticians.

9 Pianoforte Makers.

3 Perfumers.

6 Photographers.

I Picture Frame Maker.

I6 Plumbers.

2 Pocket Book Makers.

2 Polishers.

Io Porters and Messengers.

6 Portmanteau Makers.

6 Plasterers.

I Quarryman.

6 Salesmen.

5 Saddle \& Harness Makers.

I Saw Maker.

I Suda Water Bottier.

7 Shop A-sistants.

4 Stationers.

I Saith.

I Stoker.

2 Storekeepers.

I 7 Tailors.

4 Teachers.

I Traveller.

6 Tinmen.

5 Turners.

I Twine Spinner.

2 Um'rella Makers.

6 Upholsterers.

8 Watch Makers.

I Warehouseman.

3 Wheelwrights.

7 Zinc Workers. 